DOI: $10.17516 / 1997-1370-0475$

УДК 159.9

\title{
Current Approaches to Differential Diagnostics of Autism Spectrum Disorders and Similar Conditions
}

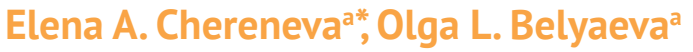 \\ and Irina Ya. Stoyanovab \\ ${ }^{a}$ Krasnoyarsk State Pedagogical University \\ named after V.P. Astafyev \\ Krasnoyarsk, Russian Federation \\ ${ }^{b}$ Tomsk National Research Medical Center of the RAS \\ National Research Tomsk State University \\ Tomsk, Russian Federation
}

Received 03.07.2019, received in revised form 30.08.2019, accepted 13.09.2019

\begin{abstract}
Autism spectrum disorders ASD is a group of pervasive developmental disorders, manifested mainly through the lack of ability to social interaction, communication disruption and stereotyped behavior. Despite of generally recognized practical and theoretical significance of studying the mechanisms of formation, it still has got little attention.

The article represents some approaches to differential diagnosis of autism and similar conditions. The authors make an attempt to find out the main reasons for such sharp increase in the number of patients suffering from this disease. The article aims analysis of existing research and contains the results of complex diagnostics and the mechanisms of disorders formation. In solving the problem of ASD formation mechanisms, clinical data, medical history data, genetic confounding factors and course of prenatal, natal and postnatal periods are used.

In their findings, the authors develop the technology for ASD and similar conditions differential diagnostics; diagnostic markers and algorithm for the development of psychological and pedagogical treatment programs are suggested.
\end{abstract}

Keywords: autism, autism spectrum disorders (ASD), diagnostics, scotopic sensitivity syndrome, neuroenergy mapping (NEM).

The reported study was funded by Krasnoyarsk Regional Fund of Science according to the research project: «Research and approbation of the model of physical training of children and teenagers with autism and other similar mental conditions.

Research area: medical psychology

\footnotetext{
(C) Siberian Federal University. All rights reserved

* Corresponding author E-mail address: elen_korn@bk.ru ORCID: 0000-0002-2845-013X (Chereneva)
} 
Citation: Chereneva, E.A., Belyaeva, O.L., Stoyanova, I. Ya. (2022). Current approaches to differential diagnostics of autism spectrum disorders and similar conditions. J. Sib. Fed. Univ. Humanit. Soc. Sci. , 15(3), 381-389. DOI: 10.17516/1997-1370-0475.

\section{Introduction}

Autism spectrum disorder is a quite common disease. According to $\mathrm{WHO}$, every $166^{\text {th }}$ child is diagnosed with autism (Morozov, 2015). Its symptoms and signs were first described in the work of psychologists in the 1920s. Such unusual mental disorder in children was first addressed by Grunya Efimovna Sukhareva, a Soviet psychologist (Morozov, 2015). Most suggest that the disease is spreading similar to an epidemic. Some researchers have noted excessive worries of doctors, which cause over-diagnostics of similar diseases. For example, in cases of sensomotor alalia, children can have disturbed communication, as in autism; in dysarthria, they have decreased social intelligence and possible abundance of stereotypy, and when suffering mutism, their speech can be destroyed, like in ASD. Some studies are devoted to autoimmune, viral and bacterial nature of autism (Simashkova (ed.), Klyushnik, Yakupova et al., 2013). Taking into account such a wide range of diseases characterized with similar symptoms, the development and implementation of differential diagnostics is very important, since it allows identifying the key pathogenesis in a given individual (Cherenova, Volodenkova, 2016). This will enable to develop more accurate and efficient way to rehabilitate the child suffering ASD (Cherenova et al., 2016).

\section{Problem statement}

Even the most common and popular methodological approaches to the ASDs treatment, in particular, behavioural ones, has not yet been proved to satisfy all the needs (Cherenova et al., 2016). Some very good or even bright results are far from improving this situation, but, in contrast, rather confirm it: the population of young autists is characterized by abnormal clinical polymorphism, and attempts to use one or another approach in all the cases, in fact, cannot ensure high results of autism correction. A differentiated approach is needed, but, then, we lack any satisfactory ASD classification (Bog- dashina, 2014; Lebedinskaya, Nikol'skaya, 1991). This paper considers one of the factors most significantly impacting clinical diversity of autism manifestations, i. e. high frequent comorbide disorders in ASD2 and the possibility of using the features of autism and comorbide disorders relations in order to increase the results of remedial work with autistic children. Comorbidity is not the only factor in the polymorphism of autism, it is also determined by asynchrony - its main dystontogenetic mechanism of development (Bogdashina, V. V. Lebedinskii， S.A. Morozov， N. V. Simashkova), and behavioural diagnostic criteria (ICD-10, DSM-IV, DSM-V) (Gillberg, Fernell, 2014).

In people suffering $\mathrm{ASD}$, other disorders are found frequently enough: mental retardation - 70-75\%; infantile cerebral palsy (CP) - 5-20\%; attention deficit/hyperactivity disorder (ADHD) - 20-25\%; genetic diseases (tuberous sclerosis, cerebral lipidosis, congenital rubella, infantile spasms, Down syndrome, Martin-Bell syndrome, etc.) - $10 \%$; epileptiform syndrome - up to $30-35 \%$ by the adult age; severe speech disorders (SSD) - frequency is not found, and other disorders. It appears that autistic disorders are often a component of developmental disorders with a complex defect structure (Lebedinskii, 2011; Morozov, 2015). Such range of comorbide disorders and frequency of autism co-occurrence make us wonder: how often can autism be identified per se, i. e. exclusively of other developmental disorders? If we suppose that these disorders and autism occur independently of each other (which, apparently, is not always the case, and which undoubtedly increases the expected frequency of autism per se), then the probability of meeting autism without the above violations (excluding SSD) will be no more than $15 \%$ (including SSD - even less). Thus, the practice of treating people with ASD requires using correction methods for not only autism, but also other disorders, and the spectrum and evidence of both autism and each of comorbide pathologies will be patient-specific. This point can 
already be regarded as a compelling argument for the choice of rehabilitation approach should be individualized, not to speak of the variants of adapted principal education program pattern, curricula and other programs (Morozov, 2015).

In 1943, autism was claimed as "rare disorder" (Kanner, 1943). For many years, the most recognizable statistic has been the one stating that autism occurs 4-5 times per 10,000 births. In 1966, Lotter revealed the first results on epidemiological study of children suffering Kanner syndrome in the former county of Middlesex. By this study, prevalence rate of this disorder was 3.0-4.5 per 10,000 (Lotter, 1966). The prevalence of autism in boys was reportedly four times higher than in girls. Since then, many studies have been conducted that give prevalence rates ranging from 3.3 to 16.0 per 10,000. From 1971 to 1973, Wing and Gould (1979) investigated the prevalence of autism in Camberwell. They studied children whose IQ was below 70 and found 22 children in the autism spectrum per 10,000. Ehlers and Gillberg (1993) examined children with IQ of 70 or higher in schools in Gothenburg and found 36 autistic children per 10,000 born between 1975 and 1983 years. In addition, they also identified children with damaged social interactions, who, however, did not show full symptoms of Asperger syndrome: 35 per 10,000. Adding the figures of these two studies gives the following prevalence - 91 per 10,000 , i. e. almost $1 \%$ of the whole population. Based on their research in Karlstad (Sweden), Kadesjo, Gillberg and Hagberg (1999) reported the prevalence of ASD for all IQ levels as $1.21 \%$.

Autism may be everywhere, but it is not detected / diagnosed everywhere with the same prevalence level (Eyal et al., 2010). For example, Swedish children are much more likely to be diagnosed as autistic than children in other countries. Thus, an epidemiological study in 1997 conducted on the western coast of Sweden revealed 46.4 cases of autism per 10,000, while in Norway it was only 5.2 per 10,000 (Fombonne, 2003). On the other hand, in Ukraine in 2011 only 1,500 cases were officially diagnosed (with the population of approximately 43 million people). In 2011, South Korean research- ers, who directly examined nearly 55,000 schoolchildren for ASD, found this disorder in every $38^{\text {th }}$ child. Two-thirds of these children studied in ordinary schools, where autism had not been identified before and no services had been done (Kim et al., 2011).

There is another question - what does increase: the number of cases of autism or merely the interest and "recognition" of this condition? If the answer is in the number of people, then what's the reason?

There are several possible explanations for what may contribute to anticipated growth in the number of autism cases:

- currently, the definition of ASD is much broader than the original one of "early childhood autism" described by Kanner;

- more accurate diagnostics classifications have been suggested compared to early days;

- most who are diagnosed with autism disorders at these days, were in the past defined as mentally retarded, imbeciles, schizophrenics, etc.;

- there really is an actual increase, but the reasons are still unknown.

Some researchers believe that the increase in cases occurs indeed, and it is not just enrichment of our knowledge about this disorder. Rimland (1994), for example, points out several possible hypotheses to explain this phenomenon: 1) increased use of antibiotics for ear infections and similar problems treating in early childhood; a side effect of antibiotics is a rapid spreading of yeast, such as candida albicans, which produce neurotoxins; 2) vaccinations; 3) environmental pollution (Bogdashina, 2014).

The literature provides very few studies on genetic, psychiatric, viral, bacterial, autoimmune, and biochemical nature of autism. In the recent years, the researchers have linked autism with digestive problems, gluten and casein intolerance.

Some investigations have shown the connection of autism with damaged amino acid and B-vitamins metabolism. Also the data contains information about increasing content of heavy metals in autistic children's hair, particularly - of mercury. However, these data are 
rather scattered and statistically of low significance. Therefore, the objectives of our study include reviewing medical data, identification of genetic confounding factors and course of the prenatal, natal and postnatal periods; estimation of the child's neurological status; analysis of the child's haematological data from their birth to the investigation moment; immunological studies, including bacterial and viral screening (PANDAS syndrome and encephalitic syndrome). Also, we conduct brain assessment using EEG to identify the cerebral cortex features, omegametry and to analyze brain stem performance. In addition, we estimate the level of energy exchange in cortical structures using neuroenergy mapping.

\section{Materials and methods}

Differential diagnostics of ASD and similar conditions have been developed and tested with support of International Institute for Autism at Krasnoyarsk State Pedagogical University named after V.P. Astafyev in cooperation with OOO (LLC) "Clinic for Modern Correctional and Developing Technologies". The sample consisted of 70 children - 10 girls and 60 boys - aged 1.5 to 5 years. The anamnesis data was collected by interviewing the parents and analyzing the children's medical records; haematomacy was carried out basing on clinical blood tests data, also provided by the parents, EEG - by the doctor of functional diagnostics with encephalogram "Mitsar", neuroenergical mapping - with the five-path neuroenergy mapper NEK-5 (invented by Scientific Research Institute of Human Brain). NEM functioned by fixing stable potentials, which are recorded on hydrogen ions in the cycle of ATP formation from glucose, being oxidized by the brain cells. The children's immune status assessment was provided by the immunogram data, collected through the haematology laboratories of Krasnoyarsk. As for the statistics the data were processed by the means of Statistica 6.0.

\section{Results and discussion}

$100 \%$ of examinees have been officially diagnosed with atypical autism. All the children have revealed violations in cognitive, communicative and emotional sphere. $40 \%$ of respondents do not have speech, and the speech is disturbed by the type of sensomotor alalia. $60 \%$ of children have echolalistic speech, and they do not use it for communication. In $95 \%$ of children we have found various types of sensory impairments, as well as multiple stereotypes and autostimulation. $80 \%$ of children have self-service difficulties and problems with getting used to the toilet or potty. In $75 \%$ of these cases autism appeared at the age of 1.5 years after the period of normal development; the parents noted a setback in speech development, behavior and other characteristics. In $20 \%$ of cases, parents noted sleep disorders in the background of autistic regression. According to the EEG data, theta-waves prevail over the alpha ones, in $2 \%$ of cases there are delta-waves. One child in the sample has been recording a long paroxysmal activity. Some children have demonstrated a decrease in electrogenesis of the cerebral cortex and changes in the wave activity in their frontal, occipital, and temporal lobes.

The obtained data are free of normal distribution law, therefore, the reliability of gaps in the results has been estimated using non-parametric statistics of the Wilcoxon test. The haematological studies have shown that $90 \%$ of children from their birth to the time of with health institutions suffer persistent violations of haematological pattern, seen as decreased haemoglobin concentration, expanding red blood cell distribution width, lymphocytosis and neutropenia. Thus, for normal oxygenation of the organs and tissues in the children's body, 130-140 GM/GL is necessary, while the showed haemoglobin decrease on average to $110 \pm 7 \mathrm{GM} / \mathrm{GL}$, which on the back of the changes in the vertebral arteries blood flow velocity ( $80 \%$ of cases, the reduction of main blood flow velocity in PA have pointed $30-40 \%$ ), can dramatically affect the oxygen supply of the child's brain cells. The decrease in haemoglobin has often been accompanied by changing the size of red blood cells, so in half of the cases the width exceeded the norm and in some cases reached $15 \%$. Such indicator as the width of red blood cells distribution can rise due to the reduction of red blood cells volume, 
as well as by changing their shape. In both cases, an anaemic condition occurs, accompanied by hypoxia of tissues and organs.

These data are consistent with the signs of damaged brain energy exchange, which can be found using neuroenergic mapping (NEM). Thus, $95 \%$ of children revealed partial oxygen starvation, mainly in the temporal and frontal lobes of the brain; in two children (1.4\%) complete decrease in the energy exchange of the cerebral cortex has been identified, following by increased products of glucose hypoxic splitting-lactate in the blood and parts of the Krebs cycle components excreted through the urine.

A full blood count has shown chronic disorders of the immune system in $97 \%$ of cases, manifested in lymphocytosis and neutropenia. In general, according to the studies, lymphocytosis with neutropenia within the norm is typical for infants. In our sample group, the number of neutrophils in the blood has reached $10 \pm 5 \%$, and the number of lymphocytes $-70 \pm 9 \%$, indicating violated immune homeostasis of the children's blood, caused either by congenital or acquired immunodeficiency. At the same time, in $100 \%$ of cases in children from one to three years old, there is an episode of viral disease recorded by a pediatrician, manifested in increased temperature, up to $40{ }^{\circ} \mathrm{C}$, and in growth of monocytes - up to $16 \pm 5$, while some cases marked with a sharp decrease or increase in the number of medium size cells. These immunograms in $100 \%$ cases have revealed a decrease in the phagocytic activity of blood cells, suppression of humoral immunity, especially due to $\operatorname{Ig} \mathrm{A}$, as well as an excessive growth in the number of T-lymphocytes against normal or slightly reduced number of B-lymphocyte, as well as significant fall of natural killer cells. $50 \%$ of children from the research sample have undergone an immunoassay of blood to Ig G: $M$ for herpes family viruses. EpsteinBarr virus (EBV) has been found in $10 \%$ of children, cytomegalovirus (CMV) - in $10 \%$, herpes viruses 1,2 and / or 6 herpes in another $10 \%$. In the remaining $20 \%$ of children, various combinations of viruses $\mathrm{CMV}+\mathrm{EBV}, \mathrm{CMV}+\mathrm{EBV}+$ Herpes type
6, Herpes types 1, 2 and $6+\mathrm{CMV}$ and / or EBV - have been found. 6 children $(8.5 \%)$ have been tested for the avidity analysis, which has showed either the absence of avid bodies to viruses or the presence of low avid bodies. Reduced avidity of immunoglobulins to viruses leads to herpes infection chronization. In fact, the above viruses are capable of causing chronic viral encephalitis of the brain, accompanied by the symptoms typical for ASD. The studies represents MRI and CT signs of proceeding viral encephalitis, which often involves the frontal, occipital, and temporal lobes in the pathogenesis, and EPI waves appear in the temporal lobes in 1 and 2 herpes types (Gillberg, C., Fernell, E., 2014). Pathogenesis in the frontal lobe causes damaged emotional-volitional sphere; the temporal lobes involved in the pathogenesis results in impaired understanding and reproduction of speech; pathogeneticity of the parietal lobe leads to sensory impairment; violation of the occipital lobe leads to scotopic sensitivity syndrome (Irlen syndrome). Antiviral treatment of three children in an immunologist has reduced manifestations of autism in these children. This indirectly confirms the viral nature of the autistic pathogenesis. Further studies will include chemiluminescence analysis, which allow calculating the intensity of free radical oxidation (FRO) processes occurring in the body of children suffering ASD.

About $70 \%$ of the information comes to us by our vision. Distorted visual perception leads to many problems in various fields of activity. Scotopic sensitivity syndrome (SSS), now better known as Irlen syndrome, is a dysfunction of visual perception independent of visual acuity, determined by traditional optometric and ophthalmological methods, which manifests itself in varying degrees in $20 \%$ of people. People suffering from Irlen syndrome see the world differently than we do. The patients with a very severe form of this syndrome may experience difficulties in perceiving people, i. e. see the world fragmentary, like in small "pieces" until they come to them closely enough. Others may experience difficulties in the perception of printed text: vagueness, fusion, apparent 
movement of letters and words on the page, etc. The mild form manifests itself in frequent headaches, fast reading fatigue, inability to determine spatial distances, poor coordination of movements, etc.

Irlen syndrome can also occur in conjunction with other disorders such as dyslexia, dysgraphia, dyspraxia, dysphasia, arrested development, hyperactivity, autism, etc. This syndrome was first described in 1983 by Helen Irlen; she proved that visual perception dysfunction lends itself to $100 \%$ correction by selecting lenses of certain shade. Although it has not been yet known how the use of colored glasses normalizes visual perception - the researches are still being taking and, hopefully, in the near future the answer to this question will be found. About $20 \%$ of the world's population suffers from this disorder. Sometimes Irlen syndrome is also called "visual dyslexia" because it is most common among the dyslexics. Helen Irlen, in her book called "Reading by the Colors", concluded that $46 \%$ of people with reading difficulties have this disorder as well. Many people who are trying to get rid of dyslexia do not achieve the results just because Irlen syndrome is the cause. That is why, when treating dyslexia and other disorders of learning activities, it is important to accurately recognize whether the person suffers also from scotopic sensitivity syndrome. The study of Irlen syndrome has also confirmed the link with other disorders, including chronic fatigue syndrome, depression, ADHD and autism.

The syndrome can be present through many different symptoms, the main of which are: photosensitivity; concentration and retention problems; headaches and migraines caused by light; distortion of letters or background in the text; tension and fatigue while reading; problems with estimating the depth of space; people with autism spectrum disorder (ASD) may also show fragmented (mosaic) perception.

To date, there are more than 100 investigations confirming the emergence of perceptual processing difficulties associated with Irlen syndrome (Bogdashina, 2014). Now there is no doubt that the use of Irlen lenses helps certain people to adjust their visual perception, and the effect varies from a slight improvement to a significant one. Still, in most cases, the treatment of Irlen syndrome by color filters should be accompanied by remedial work on the development of certain skills and abilities that was previously hampered by distorted perception. The Irlen filters do not remove the problem, but they only facilitate its solution, eliminating visual distortion.

\section{Conclusion}

1. Clinical manifestations of autism, recorded in the emotional-volitional disorders, are accompanied by EEG-signs of damaged cerebral cortex. Therefore, EEG can be used as a diagnostic method for the autism correction.

2. According to the NEM, in children with autism there are signs of partial or full damage of brain energy exchange, manifested in decreased ATP production in different parts of the cerebral cortex. This may be due to impaired blood flow in the vessels of the cervical spine and of the brain. Therefore, NEM can be used when diagnosing autism spectrum disorder to find the strategy for treatment.

3. According to the haematological data, there are homeostasis damages in the internal environment due to decreased haemoglobin, changes in the erythrocyte's shape and volume, and immune dysfunction, manifested in lymphocytosis and neutropenia in children. Thus, a comprehensive blood count can be an early diagnostic criterion for the ASD pathogenesis.

4. According to the immunogram data, children with ASD have secondary immunodeficiency, against which chronic herpetic infection can occur, which, in turn, can cause chronic brain encephalitis, manifested similarly to ASD.

5. According to the results of scotopic sensitivity (Irlen syndrome), it has been found in $80 \%$ of examinees. This suggests that the majority of surveyed respondents have deficient activity of visual cortex, which, in turn, affects the formation of perception and processing of visual information. 


\section{References}

Bogdashina, O. (2014). Sensorno-pertseptivnyye problemy pri autizme uchebnoye posobiye [SensoryPerceptual Problems in Autism: Materials for Study]. Krasnoyarsk, Krasnoyarsk State Pedagogical University named after V.P. Astafyev.

Bogdashina, O. Rasstroystva autisticheskogo spektra: vvedeniye v problemu autizma: uchebnoye posobiye [Autistic Spectrum Disorders: Introduction to the Problem of Autism: Materials for Study]. Krasnoyarsk, Krasnoyarsk State Pedagogical University named after V.P. Astafyev.

Bolezni nervnoy sistemy [Nervous System Diseases] (2001). In Meditsina [The Health Care], 1, 48-49.

Chereneva, Ye.A., Bogdashina, O.B., Kazanova, M., Li, S. (2016). Modernizatsiya idey issledovaniya autizma i razvitiya sistemy pomoshchi lyudyam s autizmom v Rossii: ot regional'noy initsiativy k globalizatsii resheniy [Modernization of Autism Research Ideas and Developing an Assistance System for People with Autism in Russia: From Regional Initiative to Globalizing Solutions]. In Psikhologicheskaya nauka i obrazovaniye [Psychology and Education], 21 (3), 131-140. DOI: 10.17759/pse.2016210315.

Chereneva, Ye.A., Volodenkova, Ye.A. (2016). Mezhvedomstvennaya model' organizatsii sistemy pomoshchi detyam s RAS v Krasnoyarskom kraye [Interdepartmental Model of Organization of the System of Assistance to Children with ASD in the Krasnoyarsk Territory]. In Autizm i narusheniya v razvitii [Autism and Developmental Disorders], 14 (4), 15-25. DOI: http://dx.doi.org/10.17759/autdd.

Churkin, A.A., Martyushov, A.N. (1999). Kratkoe rukovodstvo po ispol'zovaniyu MKB-10 v psikhiatrii $i$ narkologii [Short Guide for Using ICD-10 in Psychiatry and Narcology]. Moscow, Triada-Kh.

Diagnostic and Statistical Manual of Mental Dsorders (1993). $4^{\text {th }}$ edition. London, Washington DC, APA, 28-38.

Diagnostic and Statistical Manual of Mental Disorders (2013). $5^{\text {th }}$ edition. DSM-5. London, Washington DC, APA.

Eyal, G., Hart, B., Onculer, E., Oren, N., Rossi, N. (2010). The Autism Matrix. Cambridge, Polity Press.

Fombonne, E. (2003). Epidemiological Surveys of Autism and Other Pervasive Developmental Disorders: An Update. In Journal of Autism and Developmental Disorders, 33 (4), 365-382.

Gillberg, C., Fernell, E. (2014). Autism Plus Versus Autism Pure. In Journal of Autism and Developmental Disorders, 44 (12), 3274-3276.

Kanner, L. (1943). Autistic Disturbances of Affective Contact. In Nervous Child, 2, 217-250.

Kim, Y.S., Leventhal, B.L., Koh, Y.J. et al. (2011). Prevalence of Autism Spectrum Disorders in a Total Population Sample. In Am J. Psychiatry, 168 (9), 904-912.

Kraepelin, E. (1920). Die Erscheinungsformen des Irreseins. In Zeitschr. Ges. Neurol. Und Psychiat., $B d, 62,1-29$.

Lai, M.-Ch., Lombardo, M.V., Baron-Cohen, S. (2013). Autism (seminar). Published online. Available at: www.thelancet.com. DOI: http//dx.doi.org/10.1016/S0140-6736(13)61539.

Lebedinskaya, K.S., Nikol'skaya, O.S. (1991). Diagnostika detskogo autizma (rannii vozrast) [Diagnostics of Autism in Children (Infantile Age)]. Moscow, Prosveshchenie.

Lebedinskii, V.V. (1985). Narusheniya psikhicheskogo razvitiya u detei [Disorders in Psychological Development in Children]. Moscow, Moscow State University.

Lebedinskii, V.V. (2011). Aktual'nye problemy detskoi patopsikhologii [Topical Problems of Children's Patopsychology]. In Narusheniya psikhicheskogo razvitiya $v$ detskom i podrostkovom vozraste [Disorders of Psychological Development in Children and Adolescents]. Moscow, Akademicheskii Proekt; Triksta.

Lotter, V. (1966). Epidemiology of Autistic Conditions in Young Children-1. Prevalence. In Social Psychiatry, 1 (3), 124-135.

Luriya, A.R. (1973). Osnovy neiropsikhologii [Fundamentals of Neuropsychology]. Moscow. Moscow State University. 498 p.

Luriya, A.R. (2000). Vysshie korkovye funktsii cheloveka [Higher Cortical Functions of the Human Brain]. Moscow. Akademicheskii proekt. 
Minshew, N.J., Sweeny, J.A., Bauman, M.L., Webb, S.J. (2005). Neurologic Aspects of Autism. In Handbook of Autism and Developmental Disorders, $3^{r d}$ edn. John Wiley \& Sons, NJ, 473-514.

Mnukhin, S.S., Isaev, D.N. (1969). Ob organicheskoi osnove nekotorykh form shizoidnykh i autisticheskikh psikhopatii [On Organic Nature of Some Forms of Schizoid and Autistic Psychopathies]. In Aktualnye voprosy klinicheskoi psikhopatologii i lecheniya psikhicheskikh zabolevanii [Topical Problems of Clinical Psychopathology and Psychological Ailments Treating]. Leningrad.

Morozov, S.A. (2015). Autizm kak narushenie razvitiya so slozhnoi strukturoi defekta [Autism as Adevelopment Disorder with Complex Defect Structure]. In Deti so slozhnoi strukturoi defekta: teoriya i praktika [Children with Complex Defect Structure: Theory and Practice]. Moscow, Federal Institute of Development in Education, 23-69.

Morozov, S.A. (2015). Kompleksnoe soprovozhdenie lits s rasstroistvami autisticheskogo spectra [Complex Support of People with Autism Spectrum Disorders]. Moscow.

Rimland, B. (1994). Recovery from Autism is Possible. In ARRI, 8 (2), 3.

Rutter, M. (2013). Changing Concepts and Finding on Autism. In Journal of Autism and Developmental Disorders, 43, 1749-1757.

Simashkova, N.V. (ed.), Klyushnik, V.P., Yakupova, L.P., et al. (2013). Rasstroistva autisticheskogo spektra u detei [Autism Spectrum Disorders in Children]. Moscow.

Vliyaniye glyutena i kazeina na formirovaniye mozga/obzor statey [How Gluten and Casein Influence Brain Formation: Reviews on Studies]. Available at: http://www.elinahealthandbeauty.com/forum/viewtopic.php?t=8867

Wing, L., Gould, J. (1979). Severe Impairments of Social Interaction and Associated Abnormalities in Children: Epidemiology and Classification. In Journal of Autism and Development Disorders, 9 (1), 11-29. 


\title{
Актуальные подходы дифференциальной диагностики расстройств аутистического спектра и сходных состояний
}

\section{Е.А. Черенёва, О.Л. Беляева И.Я. Стояноваб}

${ }^{a}$ Красноярский государственный педагогический университет им. В. П. Астафьева

Российская Федерачия, Красноярск

${ }^{6}$ Томский национальный исследовательский медицинский центтр РАН

Наииональный исследовательский Томский государственный университет Российская Федеращия, Томск

\begin{abstract}
Аннотация. Расстройства аутистического спектра (РАС) представляют собой группу первазивных нарушений развития, основными маркерами которых являются отсутствие способности к социальному взаимодействию, нарушение общения и стереотипность поведения. При общепризнанной практической и теоретической значимости исследования механизмов формирования РАС они (механизмы) до сих пор остаются малоизученными.

В статье представлены некоторые подходы к дифференциальной диагностике аутизма и сходных состояний. Авторами предпринята попытка понять причины значимого прироста в последнее время пациентов с данным заболеванием. Цель статьи - анализ существующих исследований и представление результатов комплексной диагностики с учетом механизмов формирования нарушения. При исследовании указанных механизмов использованы клинические данные, сведения из анамнеза пациентов, позволяющие выявить отягощающие факторы со стороны наследственности и течения пренатального, натального и постнатального периодов. По результатам исследования авторами разработана технология дифференциальной диагностики РАС и сходных состояний, выделены диагностические маркеры, дан алгоритм разработки психолого-педагогических программ коррекции нарушений.
\end{abstract}

Ключевые слова: аутизм, расстройства аутистического спектра (РАС), диагностика, синдром скотопической чувствительности, нейроэнергокартирование (НЭК).

Исследование выполнено при поддержке Красноярского краевого фонда науки в рамках реализации проекта: «Разработка и апробация модели физической подготовки детей и подростков с аутизмом и другими сходными ментальными состояниями».

Научная специальность: 19.00.04 - медицинская психология. 